\title{
A Study on the Influence of Teenagers' Personal Characteristics in Family Purchase Decision
}

\author{
Hong Jin ${ }^{1}$ \\ School of Business, Jiangxi Normal University \\ Jiangxi, China \\ jinhong0238@hanmail.net
}

\author{
Haiyan Wang ${ }^{2}$ \\ School of Business, Jiangxi Normal University \\ Jiangxi, China \\ 1195894299@qq.com
}

\begin{abstract}
As a basic consumer decision making unit, the family has been paid more and more attention by many scholars in marketing and marketing research. The domestic scholars mostly focus on the study of individual consumer behavior, relevant research on family purchase decision is relatively small, and only researches are discussed from the perspective of parents, ignore the effect of this group of teenagers. In this paper, we can draw the conclusion that the influence factors of teenagers in family purchase decisions can be divided into three categories: social factors, family factors, individual factors through the combing of foreign literature. Based on the perspective of the personal characteristics of teenagers, this paper mainly chooses three factors that are product knowledge, circle interaction and age to discuss teenagers' influence in family purchase decision making under the China situation. In the latter part, the paper will further verify the effect of product knowledge, circle interaction, age on family purchase decision through empirical analysis.
\end{abstract}

Keywords-teenager; product knowledge; circle interaction; age; family purchase decision

\section{INTRODUCTION}

As a basic consumer decision-making unit, the family has been paid more attention from lots of scholars in marketing and marketing research, they found that in addition to individual consumers' influence on purchase decisions, the family groups also can not be ignored. Family decisionmaking is a very important consumption decision, it is also a very complicated process, because each family member can participate in family purchase and may have a different effect in every stage of the family decision.

Family members play different roles in the purchase process of any product or service. They can be the initiator, the sponsor, the information provider, the user of the product, or the ultimate purchaser in the family purchase. Early researchers focused on the influence of husband and wife in family purchase decisions, but ignored the role of teenagers in the family. Teenagers have played an important role in the family purchase decision, which has been verified by many scholars. In the process of family purchase, they can be the initiator, participant, and even the decision-maker. For example, in some snacks, their own clothing, school supplies and other products, teenagers can directly spend their money in buying their favorite products and services, and have a substantial impact on family purchases. At the same time, teenagers can also have a wide influence on family buying by changing their parents' opinions or putting forward their own suggestions to their parents. The research shows that the number of parents who ask and respect the wishes of teenagers in the family purchase process is gradually increasing in recent years. This shows that teenagers have certain influence and decision-making power in the process of family purchase behavior.

This phenomenon has aroused widespread concern in society, through the research literature, it can be found that the analysis of the influence factors of teenagers on family purchase decision mainly focused on foreign scholars, domestic research are relatively scarce in this area, coupled with the increasing influence of the youth, it is particularly urgent to research how teenagers influence family purchase decision under the China situation. Based on the analysis of the foreign literature, we can draw the conclusion that the influence factors of young people on family purchase decision can be classified into three categories: social factors; family factors; individual factors. Therefore, this study is based on the perspective of the individual characteristics of young people. In the later stage, the paper will study the impact of young people on family purchase decisions through empirical analysis, and verify the three assumptions. At present, this paper makes a review on the research theory of teenagers in family purchase decision.

\section{LITERATURE REVIEW}

\section{A. Literature Research about Teenagers}

Since 1970s, foreign scholars have found that teenagers will affect family purchase decisions and the impact of family purchase decisions will be influenced by many factors. Scholars have explored the influence of teenagers from different perspectives. Some scholars have found the gender have significant differences on family purchase decision from the perspective of gender; some scholars have found that teenagers which are in immigrant families than non immigrants have more power to participate in family purchase decision-making process from the perspective of cultural assimilation; some scholars believe that there is a certain relationship between the product type and the influence of the youth on the family purchase decision; Some scholars believe 
that in different stages of decision-making, the impact of young people on family purchase decisions is different; There are scholars studied the influence on teenagers' family purchase decision from the perspective of peer interaction and age etc.

Based on the previous literature, it can find that influencing factors of teenagers in family purchase decisions mainly are product types; stage of decision-making; age; peer interaction; gender; family structure. Though summarizing the above literature, the influence factors of family purchase decision can be divided into three categories: social factors, family factors, individual factors.

\section{B. Product Knowledge}

Product knowledge refers to the information which is related to the product, that is, consumers can use the information to determine the quality of products, functions, etc Different scholars have different views on the definition of product knowledge. The earlier concept of product knowledge was proposed is Merrie Brucks, he (1985) [1] thought that consumer product knowledge consists of two parts. Part of the subjective knowledge, that is, perceived product knowledge and information that consumers know; the other part of the objective knowledge, that is, the actual knowledge of the product that consumers obtain. Some scholars also put forward the product knowledge includes the specific knowledge which is directly related to products, such as product brands, models, types and quality, and is indirectly related to knowledge, such as consumer experience, consumption emotion. According to the definition of product knowledge by the two scholars, some scholars thought the product knowledge is mainly classified as subjective knowledge and objective knowledge of specific and non specific. In this study, with the cognitive characteristics of teenagers, the product knowledge is mainly classified into the specific knowledge that is related to the product and the consumer experience knowledge that is indirectly related to the product.

\section{Circles Interaction}

A circle is formed with the same hobby or value or occupation or interest or purpose. Different people have different circles, young people have their own circle. Circle interaction, that means communicating with their own members of circle, sharing and other acts. In the Chinese mainland with special elements, in daily life, the phenomenon of consumption together is common, the consumer circle consist of the crowd that has similarity, closer relationship. In the process of consumption, in order to maintain and strengthen the social relations with other members of the circle, the circle members will implement certain consumption behavior, so as to obtain stable emotional and tools resources. Combined with the characteristics of teenagers, this study argues that the circle interaction refers to the communication of people who have the same hobbies or values or career or interests or purpose.

\section{Age}

Teenagers are a transitional group between adolescent and young people. So far, the country has not yet issued relevant documents about clear definition of youth group. Different scholars have different definitions of adolescent age. Some scholars believe that the age range of young people is between 11 to 19 years old. Some scholars think the age range of teenagers is from 13 to 19. Hongxia Zhang, Chen Wang (2004) [2] and other scholars believe that teenagers mainly include junior middle school, high school, vocational high school and technical secondary school students. Combined with views of various scholars, and Chinese law regards 18 years old as a dividing point between minors and adults, this study suggests that teenager is a 12 years old to 18 years old people.

\section{E. Family Purchase Decision}

There are three stages in the family purchase decision, including demand identification, information search and final purchase. The demand recognition will lead to the information search, and the information search is directly related to the final purchase. In other words, when the demand is identified, it will directly lead to the occurrence of information search, and when the information search is activated, it will directly lead to the occurrence of the final purchase. Therefore, no matter what stage of the purchase decision is activated, it will directly or indirectly affect the family purchase activities.

Therefore, family purchase decisions and individual consumers purchase decision-making process are similar in the form. The biggest difference is that in the family purchase decision-making process, each member of the family can participate in family purchase and may have a different effect in every stage of the family decision. Combined with the views of various scholars, this study believes that the family purchase decision is that family is as a unit, and completes social consumption activities like individual consumers.

\section{RESEARCH MODEL}

Based on the previous studies, this paper discusses the model of the impact on the family purchase decision from the personal characteristics of teenagers. As shown in Figure 1, this study mainly selects three factors, such as product knowledge, circle interaction and age, then explores the impact of teenagers on family purchasing decision-making.

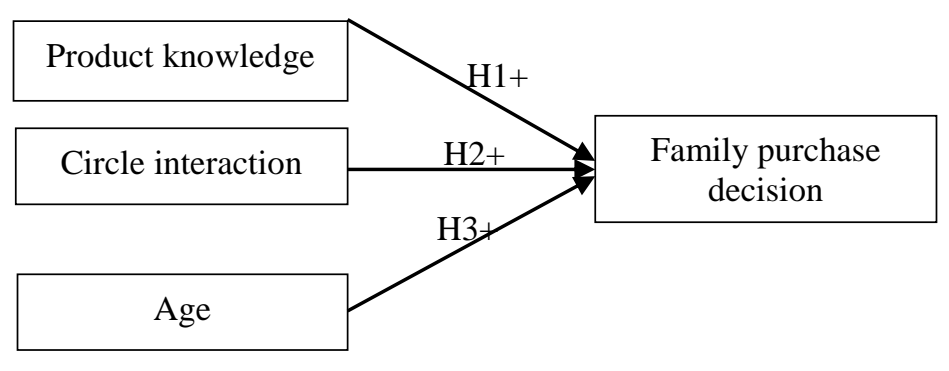

Fig. 1 Research model

\section{RESEARCH ASSUMPTIONS}

\section{A. Product Knowledge and Family Purchase Decision}

According to the theory of resource exchange, the more resources a person has, the more he has the initiative for 
family purchase decisions. When people make decisions, they prefer to someone who knows more about product information (such as relatives and friends) and ask for advice. For teenagers, performance, product information, employment status, education, parental care are their personal resources. This study focuses on the product knowledge. In general, if he has more knowledge of product and is more familiar with product, he will have a greater voice in the family purchase decision (Elizabeth S. Thomson \& Angus W. Laing, 2007) [3].

From the perspective of consumer socialization, in addition to being influenced by parents, teenagers also have a reverse intergenerational influence process, that is, parents are influenced by children's buying behavior preferences (Lackman \& Lanasa, 1993) [4]. Because in some areas of purchasing, teenagers have more knowledge and skills for their parents. The higher the level of product knowledge, the influence of teenagers on family purchase decision is greater (Karin M. Ekstrom, \& Patriya S. T et al., 1987) [5]. The following assumptions:

H1: the more product knowledge teenagers have, the impact on family purchase decisions is greater.

\section{B. Circle Interaction and Family Purchase Decision}

Consumer socialization refers to the process in which teenagers acquire knowledge, attitudes and skills as a consumer. In this process, teenagers are influenced by parents, peers, and media advertising. But teenagers are in the special period of adolescence, they are very eager to join in this peer group and become a member of them. Peer is equivalent to a circle of teenagers, and their impact to teenagers will be significantly strengthened in adolescence. Teenagers will take peer circle as the standard, their attitude, sense and so on are easily affected by the circle members. Through the process of imitation, strengthening and peer interaction in the circle, teenagers continue to obtain cognitive behavior. Through interaction with the circle, teenagers learn to evaluate products, brands and stores in a variety of ways, and gain more knowledge about the product, and enhance the sense of belonging to the group. Therefore, young people do not only consider their own choice, but also take into account preferences of circle members (Margarita Gorlin \& Ravi Dhar, 2012) [6]. The more interaction with peer, the relationship between youth and product is stronger, the degree of impact on household demand cognitive, information search is more deeply (Nibrass Hajtaïeb El Aoud \& Sabrina M. Neeley, 2008) [7]. The following assumptions:

$\mathrm{H} 2$ : the more interaction between teenagers and the peer, the impact on family purchase decisions is greater.

\section{Age and Family Purchase Decision}

In the past, many scholars have found that influence of teenagers on family purchasing decisions have a certain relationship with their age. As young people grow older, their influence on family purchase decisions increases. Whether they are buying products which have a higher correlation or low correlation with adolescents, older adults are more persuasive in their parents' faces. Through field surveys of buying food behavior of parents and children in the supermarket, some scholars found that older children get their own food is more successful. For example, when family is eating out, the child is the important source of information for family, generally as long as children's age over five, the teenagers will be allowed to provide their own ideas and suggestions in the process of choosing family dining restaurant, in addition to the number of the final purchase and decided to spend is decided by the parents (Nelson, 1979) [8]. With the continuous improvement of the family economic level, the role of teenagers is also increasing in the process of family purchase decision-making. William K. Darley and Jeen-Su Lim (1986) [9] found that in any stage of family purchase decisions, older adolescents are always more influential than younger adolescents through empirical study. The following assumptions:

H3: The older the teenagers are, the impact on family purchase decisions is greater.

\section{RESEARCH METHODOLOGY}

\section{A. Literature Research Method}

This study looks up, summarizes and sorts out relevant literature through the database system (including foreign literature database EBSCOhost, CNKI), and understand the concept of family purchase decision-making and the current situation of research on family purchase decision through reading literature. On the basis of previous studies, the paper selects the research variables, establishes the model and puts forward the hypothesis, combined with the characteristics of this study.

\section{B. Empirical Research Method}

In the later stage of this study, we will collect the required data through a series of processes, such as giving out questionnaires, recovering questionnaires, screening questionnaires and dealing with questionnaires. That SPSS21.0 software and AMOS21.0 software are used to test the reliability and validity of the questionnaire data is to ensure the authenticity and comprehensiveness of the data obtained. Only strict control of data, it is better to verify the model and assumptions.

\section{SUMMARY}

From the current situation, previous scholars mainly focus on the study of individual consumer behavior, and mistakenly believe that household consumption behavior is consistent with individual consumption behavior, so research about family purchase decision is scarce, especially for young consumer groups. The reason may be that the domestic scholars believe that teenagers do not have their own income, consumption capacity is far lower than adults, their purchase is directly completed by parents, but scholars ignore that although teenagers haven't great purchasing power, but they can influence parents for accomplishing their own purposes.

Therefore, this study can provide a reference for the domestic scholars in the field, and improve enterprise cognition for teenagers which are a huge consumer groups, they are not only direct consumers in the market, but also are 
the initiator, the influencers of family buying behavior. It is better to grasp the family and youth consumer market and provide some guidance for enterprises.

\section{REFERENCES}

[1] Merrie Brucks. The Effects of Product Class Knowledge on Information Search Behavior. Journal of Consumer Research,1985, Vol.12:2-16.

[2] Hongxia Zhang, Chen Wang, Ji Li. adolescents ' attitude toward advertising and influencing factors $[\mathrm{J}]$. Journal of Psychology,2004,(05):601-607.

[3] Elizabeth S. Thomson, Angus W. Laing and Lorna Mc Kee. Family purchase decision making: Exploring child influence behavior. Journal of Consumer Behaviour, 2007: 182-202.

[4] Lackman, C. \& Lanasa, M. Family decision-makingtheory: an overview and assessment. Psychology \& Marketing, 1993:81-93.
[5] Karin M. Ekstrom, Patriya S. Tansuhaj, Ellen R. Foxman. Children's influence in family decisions and consumer socialization: a reciprocal view. Advances in Consumer Research,1987:283-287.

[6] Margarita Gorlin, Ravi Dhar. Bridging the gap between joint and individual decisions: Deconstructing preferences in relationships. Journal of Consumer Psychology,2012,22:320 - 323.

[7] Nibrass Hajtaïeb El Aoud, Sabrina M. Neeley. Teenager-peer interaction and its contribution to a family purchase decision: the mediating role of enduring product involvement. International Journal of Consumer Studies, 2008:242-252

[8] Nelson, J.E. Children as information sources in family decision to eat out. Advances in Consumer Research, 1979,Vol.6(1):419-423.

[9] William K. Darley, Jeen-Su Lim. Family decision making in leisuretime activities: an exploratory investigation of the impact of locus of control, child age influence factor and parental type on perceived child influence. Advances in Consumer Research. 1986, Vol. 13 (1):370-374. 